\title{
Reconstruction options for locally advanced breast cancer cases and their impact on the quality of life
}

\author{
Anne Karoline Groth* (D), Alan Tibério Dalpiaz Irigonhệ (D), Stefanie Kurth¹ (D), Larissa Sydor Victor² (D), \\ Andre Luiz Bilieri Pazio² (D), Dayane Raquel de Paula² (D), Kátia Sheylla Malta Purim³ (D)
}

\section{ABSTRACT}

Introduction: Radical surgical procedures are indicated for part of the patients with locally advanced breast cancer (LABC). The improvement in the use of myocutaneous flaps allowed surgeons to perform extensive resections, a procedure that can be traumatic for women, leading to several biopsychosocial complications in a shortened survival. Objectives: This study aimed at understanding the effects of surgical treatment on the quality of survival of patients with guarded and unchanging prognosis. Methodology: The project was designed in two stages: review of medical records with a sample of 27 cases and face-to-face interviews with the administration of questionnaires in a sample of five cases among the remaining patients who underwent LABC surgery at Hospital Erasto Gaertner in Curitiba (PR). Results: On average, the answers obtained with the World Health Organization Quality of Life (WHOQOL-BREF) instrument were "regular" for physical, psychological, and environmental domains and "good" for the social relations domain. In the 12-item short-form survey (SF-12), the means were 45,125 points for the mental component and 40,875 points for the physical one. These values show the impact of advanced disease, hygienic surgery, and chest reconstruction on the quality of life of the patients, reflecting the biopsychosocial damage caused by LABC. Conclusion: The data reveal that LABC treatment is aggressive, but in patients with survival, the surgical treatment associated with chest reconstruction had surprisingly positive results in relation to quality of life.

KEYWORDS: Breast neoplasms; Quality of life; Humanization of assistance.

\section{INTRODUCTION}

Considered a public health problem by the Ministry of Health, breast cancer is the most frequent malignancy among women both worldwide and in Brazil - without taking into account nonmelanoma skin tumors. In Brazil, 59,700 new cases of breast cancer are estimated for each year of the 2018-2019 biennium, with an estimated risk of 56.33 cases per 100,000 women ${ }^{1}$.

The overall 5-year survival rate of breast cancer patients is $90 \%$, according to the American Cancer Society. This number varies based on tumor staging. In situ tumors have a success rate close to $100 \%$; in cases of disease with local involvement, this number drops to $85 \%$; distant metastasis of the disease shows an even lower value: approximately $30 \%^{2,3}$. However, mortality is significantly higher in part of the patients with locally advanced breast cancer (LABC), and surgical treatment is often only palliative or hygienic ${ }^{4}$.

$\mathrm{LABC}$ is a heterogeneous group that includes large tumors (T3 or T4), extensive nodal disease (N2 or N3), which may or may not be metastatic, and inflammatory carcinomas.
The treatment of LABC involves radical and extensive surgery, with the removal of a symbolic organ that can affect women's femininity and sexuality, leading to a series of psychological, social, and physical complications ${ }^{5}$.

The role of reconstruction surgery in the treatment of LABC and the patient's satisfaction and quality of life are topics of growing interest. In the vast majority of cases, wide mastectomy is only possible thanks to the rotation of large muscle flaps, since there is not enough skin for the primary closure of mastectomy in LABC cases. These procedures allow the mastologist to perform extensive resections of large tumors that, in other times, would have been considered unresectable ${ }^{5,6}$. We underline that these procedures are chiefly chest wall reconstructions to cover extensive soft tissue lesions and not breast reconstructions?

Since this group of patients has reduced survival and the surgical procedure is extensive, with a long postoperative recovery period, improving their quality of life after mastectomy and chest

\footnotetext{
${ }^{1}$ Universidade Positivo - Curitiba (PR), Brazil.

${ }^{2}$ Hospital Erasto Gaertner - Curitiba (PR), Brazil.

${ }^{3}$ Universidade Federal do Paraná - Curitiba (PR), Brazil.

*Corresponding author: annegroth@gmail.com

Conflict of interests: nothing to declare.

Received on: 10/19/2019. Accepted on: 03/13/2020
} 
wall reconstruction is very important. Therefore, the indication for oncologic resection should take into account the patient's quality of life.

Quality of life is a multifactorial concept that has been increasingly studied due to changes in health practices ${ }^{8}$. The World Health Organization (WHO) defines quality of life as "the individual's perception of his/her position in life in the context of the culture and value systems in which he/she lives and in relation to his/her

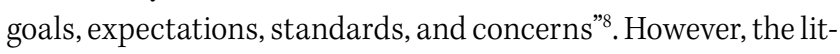
erature on the analysis of quality of life in LABC cases is scarce.

\section{OBJECTIVE}

This study aimed to describe a sample of patients who underwent LABC surgical treatment, the type of reconstruction, the complications, the disease-free interval, deaths, and objective parameters of perceived quality of life.

\section{METHODS}

We analyzed all LABC patients submitted to post-treatment reconstruction at the Hospital Erasto Gaertner in Curitiba from 2014 to 2018. The Research Ethics Committee (REC) of the hospital approved this study. Patients with pathologies other than breast cancer were excluded.

The project was designed in two stages: initially, we reviewed the medical records of all cases; next, during the follow-up appointments in the plastic surgery service, the patients were invited to answer a questionnaire with the help of the researchers, who clarified any potential doubts during the reading of the questionnaire. We chose three instruments for this stage: a survey on sociodemographic, clinical, and therapeutic characteristics and aspects related to LABC surgery; a generic quality of life survey (12-item short-form survey - SF-12); and a generic quality of life survey developed by the World Health Organization (World Health Organization Quality of Life instrument - WHOQOL-BREF).

\section{WHOQOL-BREF module}

The WHOQOL-BREF module is a questionnaire used in pathologies in which pain is a critical component. It consists of 26 questions with answers that follow a 5-point scale, and the higher the score, the better the quality of life. The instrument covers four domains: physical, psychological, social relations, and environment ${ }^{8,9}$.

\section{SF-12 Survey}

The SF-12 is a general health questionnaire first published in 1995 as part of the Medical Outcomes Study (MOS). The SF-12 assesses eight different aspects which influence the Health-Related Quality of Life (HRQoL): physical function, physical aspect, pain, general health, vitality, social function, emotional aspect, and mental health ${ }^{10,11}$.

\section{RESULTS}

We selected 27 women with LABC between 2014 and 2018 . All patients were operated by both the breast service and the plastic surgery service at the same time. All of them underwent a modified radical mastectomy with immediate chest reconstruction.

The mean age of the patients was 49 years, ranging from 22 to 86 years (Table 1). The mean lesion size at the time of resection was $138 \mathrm{~cm}^{2}$, with the largest lesion measuring $30 \mathrm{~cm} \times 30 \mathrm{~cm}$ (Table 2).

The predominant histological type was ductal carcinoma with 20 cases ( $74 \%$ of the sample), followed by spindle cell neoplasm and ductal-lobular carcinoma with two cases each, and sarcoma, adenoid cystic carcinoma, and malignant phyllodes tumor with one case each. Regarding mastectomy laterality, two cases were bilateral, 17 were on the right side, and eight on the left (Table 1).

The staging showed 13 patients with distant metastases (48\%), and, in these cases, the purpose of surgical resection was exclusively hygienic.

Regarding the immunohistochemical pattern, 15 patients had a triple-negative profile (estrogen receptor-, progesterone receptor-, and human epidermal growth factor receptor 2 HER2-negative) (Table 3).

The most commonly used form of reconstruction was chest wall reconstruction with a fleur-de-lis latissimus dorsi flap in 12 cases, followed by the V-Y flap in 11 cases (Figures 1 and 2).

Chest reconstruction was predominantly performed using extensive latissimus dorsi flaps (92.5\%), allowing a greater transference of back skin; among its variants, fleur-de-lis was the most used technique, with 12 cases (44.4\%) (Figure 3); V-Y was the second most used technique, with 11 cases (40.7\%); and island flap was used in two patients (7.4\%). In addition to the latissimus dorsi technique, the transverse rectus abdominis myocutaneous (TRAM) flap was also used in two patients (7.4\%) (Table 2).

All patients had complete primary closure of their donor area without needing skin grafting.

All cases were monitored after discharge. The most common complications were seroma and dehiscence (12 patients). Despite the extensive oncologic resection, 14 of the 27 patients progressed to distant metastasis and/or local recurrence (51.9\%) until the time of data collection, and 15 died (55.5\% mortality) (Chart 1), with a mean survival of 240.7 days.

Chemotherapy was the most used complementary, adjuvant, and neoadjuvant treatment; 20 patients benefited from this treatment, eight of whom received associated radiotherapy and two received associated radiotherapy and hormone therapy. Three patients received only radiotherapy, and four received no complementary treatment (Table 1).

No deaths were related to procedures, surgical site infections, or chest wall instability; all deaths were due to disease progression.

Regarding the quality of life survey, out of the 12 patients who survived, seven (58.3\%) refused to participate due to advanced disease or exhaustion caused by the treatment. The researchers 
invited the remaining five patients to answer questions about quality of life aspects after the chest reconstruction procedure.

The SF-12 survey was administered, resulting in two scores - one for the mental component, with an average of 40,875, and another for the physical component, with an average of 45,125.

Next, the researchers administered the WHOQOL-BREF instrument, specific for pathologies with significant pain component.

\section{DISCUSSION}

Age stands out as the main known risk factor for breast cancer in women. The incidence of breast cancer increases significantly with age ${ }^{12}$; however, the disease tends to be more aggressive in younger women ${ }^{13}$. Our study found that $48 \%$ of LABC cases occurred in under-50-year-old women, and $11 \%$ of the patients were younger than 35 years. The death rate in under-50-year-old women was $77 \%$, against $21 \%$ in women aged 50 years or older. In the subgroup of women under 35 years of age, mortality was $100 \%$. This fact confirms the epidemiological characteristic of breast cancer: the risk of developing the disease increases with time due to aging and exposure to carcinogens; on the other hand, lower age tends to be a factor of worse prognosis, especially in under-35-year-old women, as observed in our study ${ }^{12,13}$.

In $48 \%$ of the patients, the surgery was only hygienic and for pain control, as they already had distant metastases.

The surgical treatment for these advanced tumors consists of extensive radical mastectomy and large skin resections, leading to significant rib cage deformities and requiring

Table 1. General characteristics of locally advanced breast cancer (LABC) patients who underwent surgical treatment in the 2014-2018 period.

\begin{tabular}{|c|c|c|c|c|c|c|}
\hline Case & Age & Tumor Type & Staging & Complementary Treatment & Recurrence & Death \\
\hline 1 & 22 & Ductal Carcinoma & T4NOMO & $\mathrm{CT}$ & No & Yes \\
\hline 2 & 32 & Ductal-lobular Carcinoma & T4N0M1 & $C T+R T$ & Yes & Yes \\
\hline 3 & 33 & Ductal Carcinoma & T4N3M1 & $\mathrm{CT}$ & Yes & Yes \\
\hline 4 & 36 & Ductal Carcinoma & T4N1M0 & $\mathrm{CT}+\mathrm{HT}+\mathrm{RT}$ & No & No \\
\hline 5 & 41 & Spindle Cell Neoplasm & T4N0M1 & No & No & Yes \\
\hline 6 & 41 & Ductal Carcinoma & T4NOMO & $\mathrm{CT}$ & No & No \\
\hline 7 & 42 & Ductal-lobular Carcinoma & T4N1M1 & $\mathrm{CT}$ & Yes & Yes \\
\hline 8 & 42 & Ductal Carcinoma & T4N2M1 & $\mathrm{CT}+\mathrm{HT}$ & No & Yes \\
\hline 9 & 43 & Ductal Carcinoma & T4N1M1 & $\mathrm{CT}$ & No & Yes \\
\hline 10 & 43 & Spindle Cell Neoplasm & T4NOMO & RT & No & No \\
\hline 11 & 43 & Ductal Carcinoma & T4N2M1 & $\mathrm{CT}$ & Yes & Yes \\
\hline 12 & 44 & Ductal Carcinoma & T4N3M1 & $\mathrm{CT}+\mathrm{RT}$ & No & Yes \\
\hline 13 & 46 & Ductal Carcinoma & T4N2M1 & $\mathrm{CT}$ & Yes & Yes \\
\hline 14 & 50 & Malignant Phyllodes Tumor & T4NOMO & No & Yes & Yes \\
\hline 15 & 52 & Pleomorphic Sarcoma & T4NOMO & $\mathrm{CT}$ & No & No \\
\hline 16 & 52 & Ductal Carcinoma & T4N1M0 & $\mathrm{CT}+\mathrm{RT}$ & Yes & No \\
\hline 17 & 52 & Ductal Carcinoma & T4N2M1 & No & Yes & Yes \\
\hline 18 & 54 & Ductal Carcinoma & T4N1M1 & $\mathrm{CT}+\mathrm{RT}$ & Yes & No \\
\hline 19 & 57 & Ductal Carcinoma & T4N2M0 & $\mathrm{CT}$ & No & No \\
\hline 20 & 57 & Ductal Carcinoma & T4N3M1 & $\mathrm{CT}+\mathrm{RT}$ & Yes & Yes \\
\hline 21 & 58 & Ductal Carcinoma & T4NOMO & $\mathrm{CT}+\mathrm{RT}$ & No & No \\
\hline 22 & 61 & Adenoid Cystic Carcinoma of the Breast & T4NOMO & RT & Yes & No \\
\hline 23 & 62 & Ductal Carcinoma & T4N3M0 & $\mathrm{CT}+\mathrm{RT}$ & No & No \\
\hline 24 & 63 & Ductal Carcinoma & T4N1M0 & $\mathrm{CT}$ & Yes & Yes \\
\hline 25 & 66 & Ductal Carcinoma & T4NOMO & No & No & No \\
\hline 26 & 68 & Ductal Carcinoma & T4N2M1 & $\mathrm{CT}+\mathrm{RT}$ & Yes & Yes \\
\hline 27 & 86 & Ductal Carcinoma & T4N2MO & RT & Yes & No \\
\hline
\end{tabular}

$\mathrm{CT}$ : chemotherapy; RT: radiotherapy; HT: hormone therapy. 
Table 2. Surgical profile of patients submitted to surgical treatment for locally advanced breast cancer (LABC) in the 2014-2018 period.

\begin{tabular}{|c|c|c|c|c|c|}
\hline Case & Reconstruction Method & Resection & Lesion area $\left(\mathrm{cm}^{2}\right)$ & Lesion side & Complications \\
\hline 1 & $V-Y L D$ & Ro & 900 & Right & No \\
\hline 2 & Fleur-de-Lis LD & Ro & 170 & Left & Necrosis + Dehiscence \\
\hline 3 & TRAM & Ro & 45.5 & Right & Dehiscence \\
\hline 4 & $V-Y L D$ & $\mathrm{R} 1$ & 144 & Right & No \\
\hline 5 & TRAM & Ro & 130 & Left & Necrosis \\
\hline 6 & Fleur-de-Lis LD & Ro & 42 & Left & No \\
\hline 7 & Fleur-de-Lis LD & Ro & 27.3 & Right & No \\
\hline 8 & V-Y LD & Ro & 90 & Left & Seroma + Necrosis + Dehiscence \\
\hline 9 & Fleur-de-Lis LD & R0 & 96 & Right & Dehiscence \\
\hline 10 & $V-Y L D$ & Ro & 217 & Right & No \\
\hline 11 & Fleur-de-Lis LD & $\mathrm{R} 1$ & 225 & Left & No \\
\hline 12 & Fleur-de-Lis LD & Ro & 13.44 & Left & Hematoma \\
\hline 13 & Fleur-de-Lis LD & Ro & 67.6 & Right & No \\
\hline 14 & V-Y LD & Ro & 360 & Right & No \\
\hline 15 & Transverse Island LD & Ro & 140 & Right & No \\
\hline 16 & $V-Y L D$ & Ro & 132 & Right & No \\
\hline 17 & $V-Y L D$ & $\mathrm{R} 1$ & 84 & Left & No \\
\hline 18 & Fleur-de-Lis LD & Ro & 28 & Right & Seroma + Dehiscence \\
\hline 19 & V-Y LD & Ro & 90 & Right & No \\
\hline 20 & V-Y LD & R2 & 100 & Right & No \\
\hline 21 & V-Y LD & Ro & 102 & Right & Seroma \\
\hline 22 & Transverse Island LD & Ro & 77 & Right & Dehiscence \\
\hline 23 & Fleur-de-Lis LD & Ro & 7 & Left & Dehiscence \\
\hline 24 & V-Y LD & Ro & 85 & Right & No \\
\hline 25 & Fleur-de-Lis LD & Ro & 270 & Right & Dehiscence \\
\hline 26 & Fleur-de-Lis LD & $\mathrm{R} 1$ & 32.5 & Left & Seroma \\
\hline 27 & Fleur-de-Lis LD & Ro & 39 & Right & No \\
\hline
\end{tabular}

LD: latissimus dorsi flap; TRAM: transverse rectus abdominis myocutaneous.
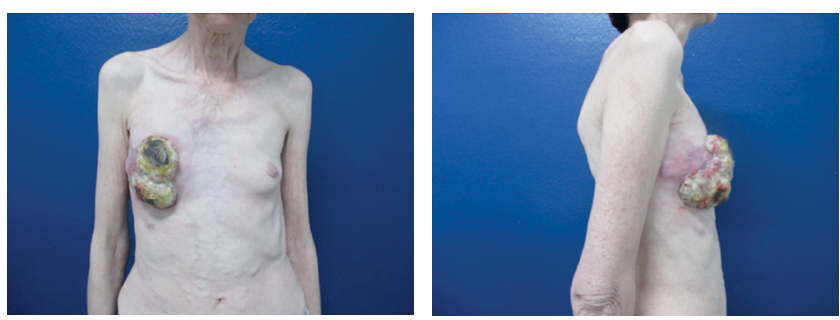
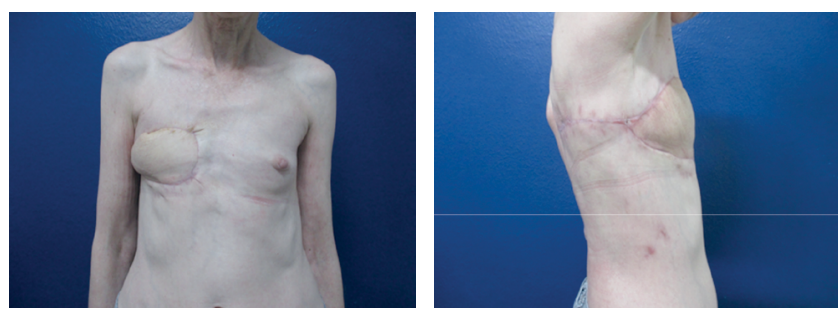

Figure 1. Right chest reconstruction with V-Y latissimus dorsi flap before and after radical mastectomy.

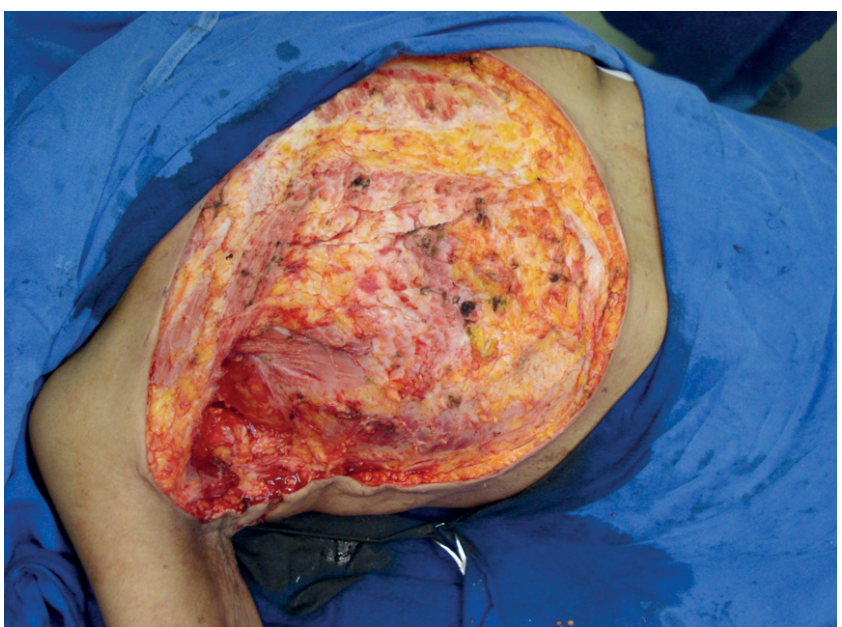

Figure 2. Intraoperative image of the right chest reconstruction with V-Y latissimus dorsi flap. 
complex reconstructions ${ }^{14,15}$. The myocutaneous flap is the first option to cover the resulting chest wall deformities, as it allows adequate coverage of soft tissues with acceptable morbidity of the donor area. Guidelines recommend offering reconstruction to all breast cancer patients and performing it immediately in the service ${ }^{16}$.

Several forms of chest wall reconstruction can be employed for repairing defects after the resection of breast tumors. Particularly in these LABC cases, skin and soft tissue deficiencies are very extensive, requiring large flaps. The latissimus dorsi flap in its V-Y and fleur-de-lis variations can offer more tissue to these defects, with excellent blood supply ${ }^{17-19}$. The incidence of total complications per patient identified in our study was $44.4 \%$. This finding is compatible with the literature ${ }^{20}$, especially in surgical wound complications, which can have a detrimental effect on the remaining treatment (delay in radiotherapy and chemotherapy).

In this study, all women were treated by the public health system (Sistema Único de Saúde - SUS) and were diagnosed at an advanced stage, perhaps due to the longer interval between suspicion and diagnostic confirmation and the lower frequency of mammograms performed compared to the private healthcare system. Nonetheless, we do not have sufficient data about the period from the diagnosis until the arrival at the reference hospital to confirm this hypothesis.

Concerning the quality of life, the BREAST-Q questionnaire is the best known and the most widely used in evaluations of breast surgeries, but we did not adopt it in our study because we performed chest reconstruction, not breast reconstruction. Therefore, we opted for the SF-12 and WHOQOL surveys.

Seven patients refused to participate in the interview, which corresponds to $58.3 \%$ of the survivors. They expressed negative feelings and aversion to returning to the hospital environment, associated with moments of distress and suffering caused by the disease.
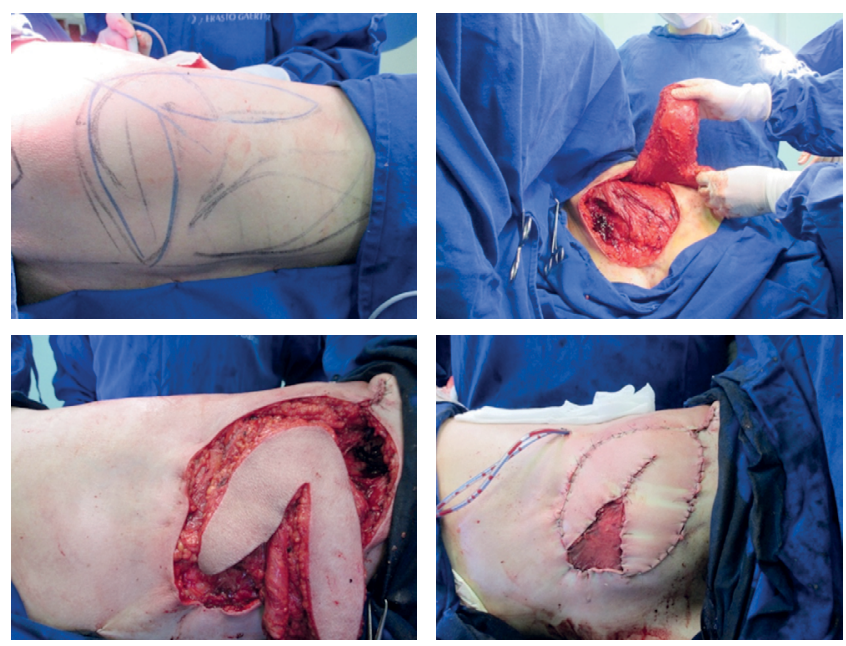

Figure 3. Radical mastectomy with chest reconstruction using the fleur-de-lis latissimus dorsi technique.
Table 3. Immunohistochemical profile of patients who underwent surgical treatment for locally advanced breast cancer (LABC) in the 2014-2018 period.

\begin{tabular}{|c|c|c|c|c|}
\hline Case & PR & ER & HER2 & KI67 (\%) \\
\hline 1 & NEG & NEG & NEG & 30 \\
\hline 2 & NEG & NEG & NEG & 80 \\
\hline 3 & POS & POS & NEG & 30 \\
\hline 4 & NEG & NEG & POS & 30 \\
\hline 5 & NEG & NEG & NEG & 85 \\
\hline 6 & NEG & NEG & NEG & 60 \\
\hline 7 & NEG & NEG & NEG & 05 \\
\hline 8 & NEG & NEG & NEG & - \\
\hline 9 & POS & POS & NEG & 20 \\
\hline 10 & NEG & NEG & NEG & 30 \\
\hline 11 & POS & POS & NEG & 10 \\
\hline 12 & NEG & NEG & NEG & 80 \\
\hline 13 & NEG & POS & NEG & 67 \\
\hline 14 & POS & POS & POS & 40 \\
\hline 15 & NEG & NEG & NEG & 80 \\
\hline 16 & NEG & NEG & NEG & - \\
\hline 17 & NEG & NEG & POS & 50 \\
\hline 18 & NEG & NEG & POS & 20 \\
\hline 19 & NEG & NEG & NEG & 70 \\
\hline 20 & NEG & NEG & NEG & - \\
\hline 21 & POS & POS & NEG & 100 \\
\hline 22 & NEG & NEG & NEG & - \\
\hline 23 & NEG & NEG & POS & 35 \\
\hline 24 & NEG & NEG & NEG & - \\
\hline 25 & NEG & NEG & NEG & 90 \\
\hline 26 & POS & POS & POS & - \\
\hline 27 & POS & POS & NEG & 60 \\
\hline
\end{tabular}

PR: progesterone receptors; ER: estrogen receptors; HER2: human epidermal growth factor receptor 2; NEG: negative; POS: positive; Ki67: cancer cell proliferation marker.

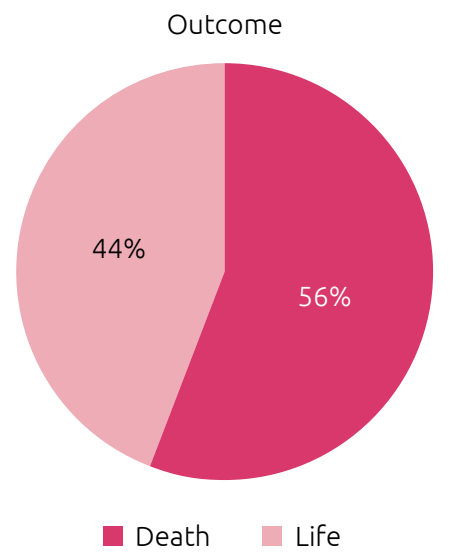

Chart 1. Outcome of locally advanced breast cancer (LABC) patients submitted to surgical treatment in the 2014-2018 period, considering all deaths until data collection. 
The patients who answered the surveys reported physical and emotional damages in the SF-12 survey concerning breast cancer treatment, which was expected given the length of the treatment.

As for the WHOQOL-BREF score, we identified loss in the physical domain, responsible for measuring pain and discomfort, energy and fatigue, and activities of daily living, as well as in the psychological domain. The social relations domain - personal relationships, social support, and sexual activity - was the most preserved and categorized as "good." This result surprised us because our hypothesis was of loss in all aspects. This finding leads us to assume the surgery can be beneficial, mainly for the local control of the tumor and wound, allowing greater social interaction.

\section{CONCLUSION}

LABC treatment is a challenge in several aspects: oncologic, reconstructive, and quality of life. Moreover, its high mortality also represents a challenge. In the sample analyzed in this study, mortality was $51.9 \%$. Despite the large oncologic resections needed in these patients, several flaps can be used for chest wall reconstruction, particularly the latissimus dorsi flap in its V-Y and fleur-de-lis variations, which is capable of closing extensive defects.

The quality of life assessment in this study was limited by the high mortality and the low adherence to the surveys, which restricted their interpretation. Nevertheless, we found signs of improvement in social relations. It is necessary to continue evaluating $L A B C$ patients to determine the benefit of such extensive surgery in this group.

\section{AUTHORS' CONTRIBUTIONS}

A.K.G.: Conceptualization; Writing - review \& editing; Supervision; Methodology; Project administration.

A.T.D.I.: Conceptualization; Writing - original draft; Data curation; Formal Analysis; Methodology; Project administration.

S.K.: Data curation; Formal Analysis.

L.S.V.: Investigation.

A.L.B.P.: Investigation; Resources.

D.R.P.: Investigation.

K.S.M.P.: Supervision.

\section{REFERENCES}

1. Santos M de O. Estimativa 2018: incidência de câncer no Brasil. Rev Bras Cancerol [Internet]. 2018 [acessado em25jul.2018];64(1):119-20. Disponível em: http://wwwl.inca.gov.br/rbc/n_64/v01/pdf/15resenha-estimativa-2018-incidencia-de-cancer-no-brasil.pdf

2. Siegel RL, Miller KD, Jemal A. Cancer Statistics, 2019. CA Cancer J Clin [Internet]. 2019 [acessado em 3 jan. 2020];69(1):7-34. Disponível em: https://doi.org/10.3322/caac.21551

3. American Cancer Society. Cancer Facts \& Figures 2019 [Internet]. American Cancer Society; 2019 [acessado em 3 jan. 2020]. 76 p. Disponível em: https://www.cancer.org/content/ $\mathrm{dam} / \mathrm{cancer-org} / \mathrm{research/cancer-facts-and-statistics/}$ annual-cancer-facts-and-figures/2019/cancer-facts-andfigures-2019.pdf

4. Tryfonidis K, Senkus E, Cardoso MJ, Cardoso F. Management of locally advanced breast cancer perspectives and future directions. Nat Rev Clin Oncol [Internet]. 2015 [acessado em 25 jan. 2020];12:147-62. https://doi.org/10.1038/nrclinonc.2015.13

5. Ferraz AMN. Avaliação da qualidade de vida de mulheres mastectomizadas [dissertação] [Internet]. Porto Alegre: Universidade Federal do Rio Grande do Sul; 2009 [acessado em 25 jul. 2018]. Disponível em: https://www.lume.ufrgs.br/ bitstream/handle/10183/15929/000690879.pdf

6. Almeida RA de. Impacto da mastectomia na vida da mulher. Rev SBPH [Internet]. 2006 [acessado em 25 jul. 2018];9(2):99-113. Disponível em: http://pepsic.bvsalud.org/scielo.php?script=sci_ arttext\&pid=S1516-08582006000200007\&lng=pt\&nrm=iso

7. Tardy M, Beguinot M, Galvaing G,Emering C,Lebouedec G, Filaire M. Breast cancer and chest wall surgery: a review. J Chir Thorac Cardiovasc [Internet]. 2019 [acessado em 25 jan. 2020];23(2):1-25. Disponível em: https://doi.org/10.24399/JCTCV23-2-TAR
8. The WHOQOL Group. The World Health Organization quality of life assessment (WHOQOL): position paper from the World Health Organization. Soc Sci Med [Internet]. 1995 [acessado em 25 jan. 2020];41(10):1403-9. Disponível em: https://doi. org/10.1016/0277-9536(95)00112-k

9. Fleck M, Louzada S, Xavier M, Chachamovich E, Vieira G, Santos L, et al. Aplicação da versão em português do instrumento abreviado de avaliação da qualidade de vida "WHOQOL-BREF" application. Rev Saúde Pública [Internet]. 2000 [acessado em 25 jul. 2018];34(2):178-83. Disponível em: http://www.revistas.usp.br/rsp/article/view/25001/26829

10. Ware JE, Keller SD, Kosinski M. How to score the SF12 physical and mental health summary scales the Health Institute. $2^{\mathrm{a}}$ ed. Boston: New England Medical Center; 1995.

11. Silveira MFS, Almeida JC, Freire RS, Haikal DS, Martins AEBL. Propriedades psicométricas do instrumento de avaliação da qualidade de vida: 12-Item Health Survey (SF-12). Ciênc Saúde Coletiva [Internet]. 2013 [acessado em 25 jul. 2018];18(7):1923-31. Disponível em: https://doi.org/10.1590/ S1413-81232013000700007

12. Momenimovahed Z, Salehiniya H. Epidemiological characteristics of and risk factors for breast cancer in the world. Breast Cancer [Internet]. 2019 [acessado em 10 fev.2020];11:151-64. Disponível em: https://doi.org/10.2147/BCTT.S176070

13. Nunes BAP, Siqueira SL, Pereira SM, Pacheco TJ, Pessanha TO, Mendonça SB. Perfil epidemiológico dos pacientes diagnosticados com câncer de mama em Campos dos Goytacazes (RJ), Brasil. Rev Bras Mastologia [Internet]. 2012 [acessado em 12 jun. 2019];22(4):117-23. Disponível em: https:// www.mastology.org/wp-content/uploads/2015/06/MAS_ v22n4_117-123.pdf 
14. Graziosi GB, Lucas FAS, Maximiano AMC, Caiado Neto BR, Prota Junior MLC. Reconstrução de parede torácica em tumores de mama localmente avançados. Rev Bras Cir Plást [Internet]. 2013 [acessado em 25 jul. 2018];28(3):64. Disponível em: http://www.rbcp.org.br/details/1346/reconstrucao-deparede-toracica-em-tumores-de-mama-localmente-avancados

15. Marcondes CA, Pessoa SGP, Pessoa BBGP, Dias IS, Ribeiro NP. Strategies for chest reconstruction following extensive resection of locally advanced breast tumors: an 11-case series. Rev Bras Cir Plást [Internet]. 2015 [acessado em 25 jul. 2018];30(3):339-44. Disponível em: http://www.dx.doi. org/10.5935/2177-1235.2015RBCP0162

16. Tanos G, Prousskaia E, Chow W, Angelaki A, Cirwan C, Hamed $\mathrm{H}$, et al. Locally advanced breast cancer: autologous versus implant-based reconstruction. Plast Reconstr Surg Global Open [Internet]. 2016 [acessado em 25 jul. 2018];4(2):e622. Disponível em: https://www.ncbi.nlm.nih.gov/pmc/articles/PMC4778893/ https://dx.doi.org/10.1097\%2FGOX.0000000000000598
17. Weledji EP, Elong FA. Primary surgical treatment of locally advanced breast cancer in low resource settings. Ann Med Surg [Internet]. 2016 [acessado em 25 jul. 2018];12:5-7. Disponível em: http://dx.doi.org/10.1016/j.amsu.2016.10.003

18. Cardoso F, Costa A, Norton L, Cameron D, Cufer T, Fallowfield L, et al. 1st International consensus guidelines for advanced breast cancer (ABC 1). Breast [Internet]. 2012 [acessado em 25 jul. 2018];21(3):242-52. Disponível em: https://doi.org/10.1016/j. breast.2012.03.003

19. Aitken ME, Mustoe TA. Why change a good thing? Revisiting the fleur-de-lis reconstruction of the breast. Plast Reconstr Surg [Internet]. 2002 [acessado em 25 jul. 2018];109(2):525-33. https://doi.org/10.1097/00006534-200202000-00018

20. WarzelhanJ, Stoelben E, Imdahl A, Hasse J. Results in surgery for primary and metastatic chest wall tumors. Eur J Cardiothorac Surg. 2001 [acessado em 25 jul. 2018];19(5):584-8. Disponível em: https://www.ncbi.nlm.nih.gov/pubmed/11343936 https://doi.org/10.1016/s1010-7940(01)00638-8 